\title{
Victimization, Offending and Resistance in Mexico: Toward Critical Discourse and Grounded Methodologies in Organized Crime Research
}

\section{Gabriella Sanchez}

To cite this article: Gabriella Sanchez (2020) Victimization, Offending and Resistance in Mexico: Toward Critical Discourse and Grounded Methodologies in Organized Crime Research, Victims \& Offenders, 15:3, 390-393, DOI: 10.1080/15564886.2020.1718048

To link to this article: https://doi.org/10.1080/15564886.2020.1718048

曲 Published online: 31 Jan 2020.

Submit your article to this journal $๘$

山 Article views: 94

Q View related articles ¿

View Crossmark data \lceil 


\title{
Victimization, Offending and Resistance in Mexico: Toward Critical Discourse and Grounded Methodologies in Organized Crime Research
}

\author{
Gabriella Sanchez (1) \\ Migration Policy Centre, European University Institute, Florence, Italy \\ KEYWORDS Organized crime; methods; qualitative; trafficking; victimization; offenders
}

In the transnational organized crime pantheon, the notion of Mexico looms large. The discourse that depicts the country as inherently violent and crime-ridden, and the accompanying policy and enforcement measures developed as security responses to counter what is construed as a quasi-mythical adversary, have allowed Mexico to emerge as global referent in the way organized crime is spoken of and fought against.

Two specific crimes lie at the core of this strategy. The first one is drug trafficking. Accompanied by the state-centric, security-driven discourse that relies on the trope of the cartel as an organized criminal entity which violence and depravity knows no limits (Astorga, 2005; Zavala, 2018), Mexico's war on drug trafficking has led to the criminalization of vast numbers of poor, brown, and indigenous women and men who participate in the drug trade seeking to reduce their precarity (Hernandez Castillo, 2019; WOLA, IDCP, DeJusticia, CIM, OEA, 2016). Counter-drug trafficking initiatives have also furthered the levels of policing, surveillance and violence experienced by vast sectors of the population and in particular, those experiencing structural marginalization (Chavez, this issue; Yates and Leutert, this issue), and those residing along the country's borders (Maldonado, this issue; Sanchez and Zhang, this issue).

The second crime is migrant smuggling, often mentioned as a proxy for irregular migration, and at times as synonym of human trafficking. ${ }^{1}$ In the narratives articulated by the Mexican state and in media and policy circles, migrant smuggling is a catch-all term that is often used to explain irregular migration as the result of the collusion of heinous smugglers with drug, sex and even nuclear weapons trafficking operators, all of whom have allegedly come together to exploit and abuse naïve and defenseless migrants in their transits through Mexico (Correa-Cabrera, 2017; Izcara Palacios, 2017; Shelley, 2010).

It would be amiss to deny the violence migrants face in the course of their journeys. There is abundant literature documenting the forms of victimization people on the migration pathway encounter in the hands of smuggling facilitators, government officials, and ordinary citizens alike. ${ }^{2}$ Yet while obviously simplistic, the monolithic characterization of smugglers as violent, atrocious men operating in collusion with other equally monstrous organized criminals has allowed for the propagation of the narratives that blame not only them for the widespread range of abuse and violence endured by migrants, but also these for relying on their services. 
Rather than explaining the demand for smuggling services as the result of the lack of availability of safe, legal and dignified paths for migration, the discourse of migration control has relied on the specter of the smuggler in an attempt to simultaneously criminalize and punish migration practices, on the grounds that fighting smuggling or trafficking activity will make migrants safer (Maldonado, this issue). There are no official numbers concerning smuggling and/or smuggling-related convictions in Mexico (McAuliffe \& Laczko, 2016; UNODC, 2018a) and trafficking data is scant (UNODC, 2018b). Yet the increase in the numbers of migrants in detention and deported from Mexico suggests they have been more often the target of migration controls than smugglers. ${ }^{3}$

By articulating practices like drug trafficking and migrant smuggling as pertaining to the domain of transnational organized crime, the Mexican state - as many others - has found a way to avoid a conversation on its role at creating the conditions leading to the spread of structural inequalities impacting those who live in and transit through its territory. Said conditions have contributed to shape the reliance on the provision and acquisition of a wide range of irregular and illicit goods and services as a path toward precarity reduction (Chavez-Villegas, this issue; Sanchez \& Zhang, this issue). In sum, through the deployment of sensationalistic and decontextualized images and narratives of organized crime, the state and its institutions have been able to create and reproduce a monolithic narrative of violence and insecurity, that by virtue of being attributed to a mythicized criminal element has allowed for the criminalization and further marginalization of the poor, women and indigenous people (Hernandez Castillo, 2019).

These assertions do not seek to suggest that organized criminality is inexistent, or that insecurity in the country does not pose a threat to the lives of people in Mexico. The levels and forms of violence they experience have indeed been documented extensively by scholars and policy makers alike (Cruz-Santiago, this issue). It is virtually impossible to find someone in Mexico who has not been impacted directly or indirectly by a criminal or violent act - many occasions, in fact more than once.

What we argue is that organized crime narratives of the kind mobilized in and on Mexico have not emerged in a vacuum. Discriminatory, racist and classist undertones have throughout Mexico's history allowed for the labeling of specific groups as inherently pathological, criminal, overly sexual or prone to violence (Moreno Figueroa \& Saldivar, 2015; Pérez Huber \& Solorzano, 2015). This is not unlike the language used by the current occupant of the White House, who has referred (precisely) to Mexican nationals as drug traffickers, criminals and perpetrators of sexual assault. ${ }^{4}$ The same can be said about the migration discourse and policy mobilized in the entire region. The construction of real and virtual walls and fences to control migration into the US, Mexico and Central America; the increase in the number of immigration and border control agents and in the funds dedicated to strengthen military and police bodies, have accompanied the claims that construct others - being those from other countries or from outside the immediate local area - as racialized, criminal invaders. (Think for example of the way Colombian and Mexican men are often racialized and gendered as narcos; or of how the term Mara or Marero has been used in reference to young Central American men, often despite their lack of a gang affiliation). None of these criminalized categories can be deemed neutral, for they all convey intrinsic notions of race, class, ethnicity and gender.

There is another aspect that we consider even more concerning than the discourse. That is the fact that the scholarship of criminalized practices at the center of Mexico's security strategy 
has hardly been the subject of systematic, empirical and - most importantly - critical analyses. Despite the hyper-visibility of criminalized and migratory processes in and across Mexico, academic production involving grounded, bottom-up, community-based research with those directly experiencing criminalization in the country is limited at best. The research that exists has often neglected to reflect on its own epistemological trajectory - or as Fonow and Cook highlight, "to examine critically, and explore analytically the nature of [its] research process" (2005, p. 2218). It has also failed to remain critically aware of the ways in which it acquires and re/produces data and knowledge (Baird \& van Liempt, 2016). In other words, despite the onslaught of researchers and policymakers in both Mexico and the United States exploring organized crime issues, scholarship that empirically examines these practices while analyzing their articulation as criminal on the one hand, and that engages directly with those at the center of the process - that is, those portrayed as criminal, violent others-is scant. This has in turn led to the body of literature on Mexican organized crime to be largely constructed on state-centric, anecdotal and often sensationalistic claims - claims articulated by government officials, judicial officers, policy makers and academic experts who have spent scant if any time in the field. This means that while crimes like drug trafficking, human trafficking, migrant smuggling and the disappearances they have generated are obligated topics of the academic and policy repertoire of organized crime in Mexico, their epistemological basis is plagued by research biases and severe knowledge gaps.

Granted, critical, empirically-based research on highly politicized criminalized practices is difficult to carry out. And therefore citing the clandestine nature of illicit markets, or often legitimate concerns over personal safety, many scholars and policy makers have turned to study Mexico's security landscape from afar, in places completely inaccessible to those whose lives they so meticulously if un-empirically chronicle. Our collective goal through this special issue is to demonstrate that when examined from the field, these so-called criminal underworlds - fabricated in the safe confines of think tanks and academic institutions - are constituted, rather than by mafia-like criminals, by ordinary people doing the best they can to survive.

\section{Notes}

1. Migrant smuggling refers to the facilitation of a person's entry into a country other than his or her own uninspected; human trafficking is defined as the recruitment, transportation, transfer, harboring or receipt of persons, by means of the threat or use of force or other forms of coercion, of abduction, of fraud, of deception, of the abuse of power or of a position of vulnerability or of the giving or receiving of payments or benefits to achieve the consent of a person having control over another person, for the purpose of exploitation.

2. See for example the two volumes from Mexico's National Commission for Human Rights (CNDH) on the kidnapping of migrants in 2009 (www.cndh.org.mx/sites/all/doc/Informes/ Especiales/2009_migra.pdf) and 2011 (https://www.cndh.org.mx/sites/all/doc/Informes/ Especiales/2011_secmigrantes.pdf).

3. Today, Mexico apprehends and deports more Central American migrants than the U.S. "In the first seven months of the year, more than 123,00 migrants were detained - 69 percent higher than those in the same period last year. Almost 94.000 have been repatriated, 54 percent more than those returned to their countries during the same period in 2018." See Excelsior, 2019. "Aumenta el número de migrantes detenidos en México en 2019." Diario Excelsior, 9 August 2019. Available from: https://www.excelsior.com.mx/nacional/aumentanumero-de-migrantes-detenidos-en-mexico-en-2019/1328947. 
4. "They're bringing drugs. They're bringing crime. They're rapists." Statements from then candidate to the US Presidency Donald T. Trump. Washington Post (2015). Full text: Donald Trump announces a presidential bid. Washington Post, 16 July 2015. Available from: https://www.washing tonpost.com/news/post-politics/wp/2015/06/16/full-text-donald-trump-announces-a-presidentialbid/.

\section{Disclosure statement}

No potential conflict of interest was reported by the author(s).

\section{ORCID}

Gabriella Sanchez (D) http://orcid.org/0000-0002-6543-346X

\section{References}

Astorga, L. (2005). El siglo de las drogas: el narcotráfico, del Porfiriato al nuevo milenio. Mexico City, Mexico: Plaza y Janés.

Baird, T., \& van Liempt, I. (2016). Scrutinising the double disadvantage: Knowledge production in the messy field of migrant smuggling. Journal of Ethnic and Migration Studies, 42(3), 400-417. doi:10.1080/1369183X.2015.1103172

Correa-Cabrera, G. (2017). Trafficking in persons along Mexico's eastern migration routes. The role of transnational criminal organizations. Washington, DC: Wilson Center.

Fonow, M., \& Cook, J. A. (2005). Feminist methodology: New applications in the academy and public policy. Signs: Journal of Women in Culture and Society, 30(4), 2211-2236. doi:10.1086/ 428417

Hernandez Castillo, R. A. (2019). Racialized geographies and the" War on Drugs": Gender violence, militarization, and criminalization of indigenous peoples. Journal of Latin American and Caribbean Anthropology, 24, 635-652. Early view, online version of record. doi:10.1111/jlca.v24.3

Izcara Palacios, S. P. (2017). Prostitution and migrant smuggling networks operating between central America, Mexico, and the United States. Latin American Perspectives, 44(6), 31-49. doi:10.1177/0094582X17699910

McAuliffe, M., \& Laczko, F. (2016). Migrant smuggling data and research: A global review of the emerging evidence base. Geneva, Switzerland: International Organization for Migration.

Moreno Figueroa, M., \& Saldivar, E. (2015). Comics, Dolls and the Disavowal of Racism: Learning from Mexican Mestizaje. Liverpool: Liverpool University Press.

Pérez Huber, L., \& Solorzano, D. G. (2015). Visualizing everyday racism: Critical race theory, visual microaggressions, and the historical image of Mexican banditry. Qualitative Inquiry, 21(3), 223-238. doi:10.1177/1077800414562899

Shelley, L. (2010). Human trafficking: A global perspective. Cambridge: Cambridge University Press.

UNODC. (2018a). Global study on the smuggling of migrants. Vienna: Author.

UNODC. (2018b). Global report on trafficking in persons. Vienna: Author.

WOLA, IDCP, DeJusticia, CIM, OEA. (2016). Women, drug policies and incarceration: A guide for policy reform in Latin America. Washington, DC. Retrieved from: https://womenanddrugs.wola.org/womendrug-policy-and-incarceration-a-guide-for-policy-reform-in-latin-america-and-the-caribbean/

Zavala, O. (2018). Los cárteles no existen: Narcotráfico y cultura en México. Mexico: Malpaso Ediciones. 